\title{
Odour Impact Monitoring for Landfills
}

\author{
Magda Brattoli, Gianluigi de Gennaro \\ and Valentina de Pinto \\ Department of Chemistry, University of Bari
}

Italy

\section{Introduction}

In the perspective of the improvement of life quality and citizens wellness, odour pollution is becoming a more and more relevant topic. In fact, among the variables that could influence the citizens' sense of a healthy environment, odour emissions play an important role, as they deeply affect the human life quality and psycho-physical wellness.

An odour is a mixture of light and small molecules, that are able to stimulate an anatomical response in the human olfactory system (Craven et al., 1996). The nose represents the interface between the ambient air and the central nervous system; in fact chemicals interact with the olfactory epithelium which contains different olfactory receptors and the signals are transmitted to the brain, where the final perceived odour results from a series of neural computations. The olfactory signals are processed also thanks to the memory effect of previous experienced smells, thus accounting for the high subjectivity of the odour perception (Freeman, 1991; Pearce, 1997).

In this way the sense of smell permits to detect the presence of some chemicals in the ambient air and for this reason odour perception is sometimes associated with a risk sensation (Dalton, 2003; Rosenkranz \& Cunningham, 2003) or however it represents an indicator of a not salubrious situation for people suffering for olfactory pollution. Although odours do not involve toxic effects for human health, they could cause both physiological symptoms (respiratory problems, nausea, headache) and psychological stress (Schiffman, 1998). For this reason in the last decade the scientific community has been developing an increasing attention for odour pollution, generally caused by different types of industrial activities such as tanneries, refineries, slaughterhouses, distilleries, and above all civil and industrial wastewater treatment plants, landfills and composting plants. Moreover, the proximity of these industrial plants to residential areas really affects the acceptability of such activities causing population complaints (Nicell, 2009; Stuetz \& Frechen, 2001; Yuwono \& Lammers, 2004).

This paper focuses on the necessity of a proper management for odour emissions during the processes and the critical phases of landfills, and on the development of a proposal for a guideline to evaluate odour emissions and odour impact. So, the methodological approach of the guideline is described and compared with those commonly adopted in odour regulations. 


\section{Landfill odour emissions}

Landfills are the most common way of disposing of municipal solid wastes (MSW).

Among the several existing types of industrial plants that generally cause odour nuisance, they represent one of the major sources of odour emissions and complaints.

Emissions from municipal landfill sites approximately consist of $65 \% \mathrm{v} / \mathrm{v}$ methane and $35 \%$ $\mathrm{v} / \mathrm{v}$ carbon dioxide (Allen et al., 1997), while trace volatile organic compounds (VOC) represent less than $1 \% \mathrm{v} / \mathrm{v}$ of landfill gas. Odour emission is attributed to the presence of low concentrations of VOC, in particular esters, organosulphurs, alkylbenzenes, limonene, other hydrocarbons and hydrogen sulfide (Young \& Parker, 1983).

Odour emissions originate principally from the atmospheric release of compounds deriving from biological and chemical processes of waste decomposition (ElFadel et al., 1997). In particular, the anaerobic degradation of the biodegradable fraction of the MSW causes several environmental problems such as methane and leachate production and VOC and odours emission (Scaglia et al., 2011).

The odorous characteristics of landfill gas may vary widely from relatively sweet to bitter and acrid, depending on the concentration of the odorous substances within the gas. These concentrations could be affected by several factors, such as the waste composition, in particular its organic fraction (OFMSW), the decomposition stage, the rate of gas generation and the nature of microbial populations within the waste. Moreover the weather conditions (wind speed and direction, temperature, pressure, humidity) significantly affect the extension of the area in which odours spread away from the landfill boundaries.

Generally the presence of OFMSW in landfills can be reduced by three different approaches (Scaglia et al., 2011):

- $\quad$ separation of OFMSW to produce compost;

- $\quad$ waste burning to produce energy;

- mechanical-biological treatment (MBT) (composting-like process) to produce a stabilized material.

The MBT is often carried out directly in landfill plants; it consists in a solid-state aerobic process (composting-like process) during which forced aeration in the biomass allows the microbial oxidation of the organic fraction of MSW, reducing its potential impact (Scaglia \& Adani, 2008; Scaglia et al., 2010). In this process it is necessary to maintain the optimal aeration conditions in the biomass in order to avoid the production of intermediates of the anaerobic metabolism (e.g., sulphide and nitride compounds). In fact, odour emission mainly occurs during the first phase of the aerobic process when oxygen limitation for the aerobic biological process becomes more evident. Oxygen limitation could be due to both the high rate of $\mathrm{O}_{2}$ consumption, because of the great amount of degradable organic matter present in the biomass, and to insufficient air diffusion.

However the main sources of odour emissions are represented by fresh waste dumps stored everyday. In order to reduce these emissions, it is opportune using cover materials after daily waste storage in landfills. Conventionally, materials deriving from the construction and demolition industry have been considered suitable to the purpose (Hurst et al., 2005), but other materials have been regarded as an alternative, such as paper mill sludge, fly ash, mulched wood material and foams (Bracci et al., 1995; Bradley et al., 2001; Carson, 1992; Hancock et al., 1999; Shimaoka et al., 1997). In the perspective of a sustainable waste management, the use of the stabilized materials derived from MBT process is deemed suitable for reducing odour emissions. 


\section{Odour emission monitoring and control}

Odour emission monitoring and its regulation are characterized by a great complexity due principally to the strict association of odour pollution to human perception. For this reason, odour emission monitoring and its control can not be rigorously equalled to air quality monitoring.

Commonly, for air quality monitoring the conventionally used approaches are focused on: impact evaluation and estimation of the pollutant relapse on the territory. This aspect is generally attained by means of decision making support tools and, in particular, of dispersion models that estimate the downwind concentration according to emission rates, meteorological parameters, that affect the transport and the diffusion of the pollutants, and topography of the site. About odour emissions, dispersion models are considered a useful tool for predicting odour impact. However, there are some typical aspects that have to be taken into account when the modelling is performed for odour. First of all, odour is a mixture, composed by a lot of chemical substances, with different physical and chemical properties, that can react each other and change their composition. In a dispersion model, odour is considered as a pure substance rather than a combination of different chemicals. So, it is modelled as a single indicator compound, usually with a low odour threshold and a high emission rate (Drew et al., 2007).

Moreover, in many cases the dispersion models are not suitable to describe the human odour sensation that is activated by the odour stimulus in few seconds (Schauberger et al., 2002). Odours therefore produce a response in the receptor quicker than other atmospheric pollutants (Irish Environmental Protection Agency, 2001). Furthermore odour emissions are discontinuous, alternating periods of high emission rate with periods of low emissions (Drew et al., 2007); greater annoyance is mainly caused by short periods of odour than by longer lasting odour emissions, as the olfactory sense is able to adapt to persistent odours, thereby reducing annoyance (Guideline on odour in ambient air [GOAA], 1999). For this reason, the fluctuations from the mean concentration, rather than the mean value, frequently affect the odour perception (Best et al., 2001). So, the average time used by dispersion models for the estimation of odour concentration represents another critical point.

The dispersion models are normally based on long averaging time periods, usually 1 hour, whereas odours can generate community complaints from a series of short detectable exposures (Mahin, 2001; Mussio et al., 2001). The concentration values, predicted in this way, represent the concentrations of a mixed sample of ambient air that have been sampled over a 1-h period. Since meteorological conditions are highly variable over very short periods of time, the use of a 1 hour average masks the shortterm peak odour concentrations that are experienced by the population (Nicell, 2009). However, 1 hour averaging time is also used because the most frequently available atmospheric input data are recorded as hourly averaged variables. An approach for overcoming this drawback involves the use of short averaging times for considering concentration peaks and thereby obtaining a more accurate prediction of odour dispersion. New generation air dispersion models can run at averaging times of less than $1 \mathrm{~h}$, as half-hourly mean (Schauberger et al., 2002) or 10 - minute averages (Nicell, 2009), even if they are typically not used by regulators. Furthermore only few dispersion models are able to estimate short-term concentrations, while most models use highly simplified and uncertain methods to convert the commonly estimated one- 
hour average concentrations to short-term averages (Nicell, 2009; Schauberger et al., 2002).

monitoring through standard methodologies. Air quality monitoring is commonly performed using conventional analytical methodologies that produce a list of substances involved and their concentration. Even for odour emissions, an instrumental approach, usually the conventional Gas Chromatography coupled with Mass Spectrometry (GC/MS) (Davoli et al., 2003; Dincer et al., 2006), is widely used in order to evaluate the odorous air chemical composition. Nevertheless the perceived odour results from many volatile chemicals, often at concentration lower than the instrumental detection limit, that synergically interact or add according to non predictable laws (Craven et al., 1996; Vincent \& Hobson, 1998; Yuwono \& Lammers, 2004). Furthermore the GC/MS is expensive and does not give information about human perception, thus not allowing a linear correlation between a quantified substance and an olfactory stimulus (Di Francesco et al., 2001).

In fact, a reliable odour monitoring technique must be representative of human perception, trying to overcome the subjectivity due to the human olfaction variability and providing accurate and reproducible results. The more sensitive and broader range odours detector is undoubtedly the mammalian olfactory system; so, there is a growing attention for odour measurement procedures relying on the human nose as detector, in compliance with a scientific method (Craven et al., 1996; Pearce, 1997; Walker, 2001). So, dynamic olfactometry represents the standardized method for the determination of odour concentration; it is based on the use of a dilution instrument, called olfactometer, which presents the odour sample, diluted with odour-free air according to precise ratios, to a panel of selected human assessors. In the last years, the conventional instruments for chemical analysis (GC/MS) have been coupled with sensory detection developing a gas chromatography-olfactometry (GC-MS/O) technique in order to study complex mixtures of odorous compounds. GC-MS/O allows a deeper comprehension of the odorant composition in terms of compounds identification and quantification, offering the advantage of a partial correlation between the odorant chemical nature and the perceived smell (Friedrich \& Acree, 1998; Lo et al., 2008).

Both analytical and sensorial methods provide punctual odour concentration data and do not allow to perform continuous and field measurement, useful for monitoring odour emissions that can vary over the time in consideration of the industrial processes. To the purpose, artificial olfactory instruments (E - Noses) miming the biological system (Craven et al., 1996; Pearce, 1997; Peris \& Escuder-Gilabert, 2009; Snopok \& Kruglenko, 2002) have been developing. E-Noses are based on "an array of electronic-chemical sensors with partial specificity to a wide range of odorants and an appropriate pattern recognition system" (Gardner \& Bartlett, 1994). The chemo-electronic signals are processed by pattern recognition techniques (i.e., artificial neural networks, multivariate statistical analysis) for their classification in order to identify odour and quantify the concentration. These systems present lower costs of analysis, rapidity of the results and allow to carry out continuous field monitoring nearby sources and receptors. After a training phase, electronic noses are able to preview the class of an unknown sample and consequently to associate environmental odours to the specific source.

In the following paragraphs the principal methodologies for odour monitoring (dispersion models, chemical characterization, dynamic olfactometry and chemical sensors) will be described, presenting their applications for landfill monitoring. 


\subsection{Dispersion models}

Atmospheric dispersion models are computer programs that use mathematical algorithms to simulate how pollutants disperse in the atmosphere and, in some cases, how they react. Since it is impossible to use direct measurements to evaluate odour dispersion over a long range and/or make predictions, dispersion models are widely applied to odour investigation. The use of dispersion models is indispensable in the studies for authorization processes, evaluation of odour impact at the receptors and process control.

Dispersion models calculate odour concentration at ground level using emission data, meteorological data and orographic data.

Emission data can be determined analyzing samples, collected at each source of the plant, by dynamic olfactometry and then calculating the odour emission rates (Hayes et al., 2006; Sironi et al., 2010). The indispensable input meteorological data include wind speed, wind direction, air temperature and solar radiation in the study area over a long enough period (Hayes et al., 2006; Sironi et al., 2010). Orographic data are useful to take into account the effects of the topography on odour dispersion (Chemel et al., 2005).

Simulated concentrations at receptors can be processed to calculate parameters to be compared with reference limits, such as annual or daily average values expressed as concentration percentiles. The averaged odour concentration, calculated at each receptor, has to be compared with exposition criteria employing percentiles, that represent a distribution of concentration values. The choice of a percentile indicates a level of exposition to odour nuisance, since it represents a value below which a fixed percentage of observations falls. For example, the $98^{\text {th }}$ percentile of one year hourly simulations is equal to 175 hours; this means that the $98^{\text {th }}$ percentile of a series of values is the datum not exceeded by the $98 \%$ of the distribution values (Capelli et al., 2010; Romain et al., 2008).

Three main categories of atmospheric dispersion models are currently used: Gaussian, Lagrangian, and Eulerian (Dupont et al., 2006):

- Gaussian models are relatively simple statistical models describing the scalar plume downwind from a source point as a Gaussian-type curve. This kind of models are suitable for flat areas but not for areas with a complex orography (McCartney \& Fitt, 1985). These are parametric models, because they calculate odour concentrations on the basis of a set of input parameters. Even if they introduce extreme simplifications of the phenomena, they are quite simple to apply, and so, widely used (Chen et al., 1998; Hayes et al., 2006; Holmes \& Morawska, 2006; Wang et al., 2006).

- Lagrangian models deduce average concentration and deposition rates from the trajectories of numerous individual particles. The odour concentrations are calculated considering the random paths of single particles and require many simulations of particles paths to achieve good results. According to the Lagrangian approach, the virtual particles follow a prescribed wind field modified by turbulence, and the model computes their spatial trajectories. As they cannot calculate the flow characteristics themselves, these models require velocity and turbulence fields to be prescribed a priori, which is not possible in most heterogeneous, real-world situations (Holmes \& Morawska, 2006; Kaufmann et al., 2003; Stohl et al., 1998; Stohl \& Thomson, 1999).

- In Eulerian approaches the mean particle concentration is directly calculated by solving the advection-diffusion equation in a tridimensional reference grid. Thus, the Eulerian approach is simpler than the Lagrangian one. These models are generally applied on mesoscale or urban scale, especially in the presence of complex chemical reactions. CFD 
(Computational Fluid Dynamics) models have been developed in Eulerian framework

for predicting flow and transport processes in urban or industrial environments taking into account the effects caused from buildings presence (Holmes \& Morawska, 2006).

Furthermore puff models have been developed in which the pollutant is assumed to be emitted as a large number of puffs in rapid succession. They are non-stationary in time. This kind of models can be applied on wide domains or areas with complex orography (Holmes \& Morawska, 2006; Wang et al., 2006).

Dispersion models are generally used in conjunction with other odour monitoring techniques to evaluate the landfill odour impact at the surrounding areas ( $\mathrm{Li}, 2003$; Romain et al., 2008) and to analyze the variation in odour exposure within communities surrounding landfill sites (Sarkar et al., 2003).

\subsection{Chemical characterization}

Chemical analysis of odour samples is able to provide the chemical composition of the single compounds in a mixture and their concentrations. Generally, characteristic compounds generating odours in a landfill are ammonia, hydrogen sulfide and VOC (volatile organic compounds) like amines, mercaptans, sulfur compounds, saturated and unsaturated fat acids, aldehydes, ketones, hydrocarbons, limonene, chlorinated compounds, alcohols, etc. (Bruno et al., 2007; Capelli et al., 2008; Dincer et al., 2006; Leach et al., 1999; Ribes et al., 2007).

VOC samples are collected using canisters (Camel \& Caude, 1995; Kumar \& Viden, 2007; Ras et al., 2009), polymer bags (Dincer et al., 2006; Ras et al., 2009) or adsorbent materials (Ras et al., 2009). Adsorbent materials, packed in appropriate tubes, represent a handier sampling method than canisters and bags because they allow to sample a great volume of air reducing the analytes in a small cartridge. The critical point is the choice of adsorbents (usually porous polymers or activated carbon, graphitized carbon black and carbon molecular sieves) (Camel \& Caude, 1995; Gawrys et al, 2001; Harper, 2000; Matisová \& Škrabáková, 1995) that depends on the chemical feature of compounds to be sampled (Kumar \& Viden, 2007). A combination of different adsorbents is preferred to sample a wide range of compounds without breakthrough problems (Harper, 2000; Wu et al., 2003).

Sampling on adsorbent materials can be applied in "active" mode (defined volume of sample air pumped at a controlled flow-rate) or "passive" mode (without the use of a pump but through direct exposure to the atmosphere) (Bruno et al., 2007; Gorecki \& Namiesnik, 2002; Seethapathy et al., 2008). For both procedures the analytes can be recovered through thermal desorption or liquid extraction (Bruno et al., 2007; Demeestere et al., 2007, 2008; Ras et al., 2009; Ras-Mallorquì et al., 2007). After sampling, preconcentration techniques are required: gas-solid enrichment using adsorbent materials, solid phase micro extraction (SPME), cryogenic preconcentration and purge and trap (Davoli et al., 2003; Demeestere et al., 2007; Ras et al., 2009). Since odours are complex mixtures of volatile organic compounds, in the gas-chromatographic analysis of odour samples critical steps are the choices of the appropriate column and detector to achieve a simultaneous determination of as much compounds as possible (Demeestere et al., 2007; Ribes et al., 2007; Zou et al., 2003).

Nevertheless, it is very difficult to establish a correlation between analytical measurements and odour intensities perceived, especially because of the different interactions between odourants in a mixture.

Example of applications of chemical characterization for landfill monitoring. Not many studies have been carried out on chemical characterization of odours in ambient air at a 
landfill site. Davoli et al. have analyzed air samples from different landfills using SPME and GC-MS to better establish specific markers of olfactory pollution (Davoli et al., 2003). Dincer et al. have investigated the composition of odorous gases emitted from a municipal landfill to find a relationship between odour concentration and chemical concentration of VOC by GC-MS (Dincer et al., 2006; Dincer \& Muezzinoglu, 2006). Ambient air monitoring has been conducted at landfills using thermal desorption and GC-MS determination of VOC to identify the compounds responsible of potential odour nuisance (Capelli et al., 2008; Leach et al., 1999; Ribes et al., 2007; Zou et al., 2003).

\subsection{Dynamic olfactometry}

Nowadays the dynamic olfactometry is the standardized method used for determining odours concentration and evaluating odour complaints (CEN, 2003; Schulz \& van Harreveld, 1996). Dynamic olfactometry is an instrumental sensory technique that employs the human nose (a panel of human assessors) in conjunction with an instrument, called olfactometer, which dilutes the odour sample with odour-free air, according to precise ratios, in order to determine odour concentrations.

Odour sampling is carried out using odourless containers and sampling lines. In particular, for olfactometric analysis, polymer bags of Tedlar ${ }^{\circledR}$ (polyvinyl fluoride) or Nalophan ${ }^{\circledR}$ (polyethylene terephthalate) are used for the collection of odorous compounds.

For samples of ambient air or punctual emissions, odour bags are filled using a depression pump that works on the basis of the 'lung' technique: the bag is placed inside a rigid container evacuated using a vacuum pump (AS/NZS, 2001; ASTM, 2004; CEN, 2003).

In the case of areal sources, instead, it is necessary to use auxiliary devices to collect odour samples, because it is difficult to cover the whole emission area during sampling and so representative sampling sites have to be established (Bockreis \& Steinberg, 2005). The investigations are conducted using a hood or a wind tunnel, depending on the measurement conditions. For olfactometric analysis the examiners are selected in compliance with a standardized procedure, performed using reference gases; only assessors who respect predetermined repeatability and accuracy criteria are selected as panelists.

Commonly, there are two standardized methods for the presentation of odour samples to panel: forced choice and yes/no method (AS/NZS, 2001; ASTM, 2004; CEN, 2003). In the forced choice method, two or more sniffing ports are used; the odour sample is presented at one port, and neutral air at the other port(s). In this case, the examiners have to compare the different presentations and to choice the port from which odour exits. In the yes/no method each examiner sniffs from a single port and communicates if an odour is detected or not. Odorous sample diluted with neutral air or only neutral air can exit from the sniffing port.

The process continues until each panelist positively detects an odour in the diluted mixture; at this stage the panelist has reached the detection threshold for that odour (AS/NZS, 2001; ASTM, 2004; CEN, 2003).

Since odour perception is a logarithmic phenomenon (Stevens, 1960), in this type of measurements it is necessary taking into account that odour concentration is associated to odour intensity though a defined logarithmic relation.

The concentrations may be expressed as threshold odour numbers (TON) or dilution to threshold $(\mathrm{D} / \mathrm{T})$ ratios. Although the concentrations are dimensionless, it is common to consider them as physical concentrations, and to express them as odour units per cubic meter $\left(\mathrm{ou} / \mathrm{m}^{3}\right)$ (Frechen, 1994; Koe, 1989). 
Although dynamic olfactometry represents the standardized objective method for the determination of odour concentration, it is affected by some limitations. First of all it provides punctual odour concentration data, but it is not sufficient to evaluate completely a case of olfactory nuisance, because it does not allow to perform continuous and field measurements, useful for monitoring the industrial processes causing odour emissions. Moreover, dynamic olfactometry considers the whole odour mixture and do not discriminate the single chemical compounds and their contribution to the odour concentrations. Odour samples are difficult to store, because of their instability, and so require rapid time of analysis. Finally, as it is well-known, olfactometry is too timeconsuming and quite expensive and moreover frequency and duration of analysis are limited.

Example of applications of dynamic olfactometry for landfill monitoring. Olfactometric measurements have been employed by Sironi et al. (Sironi et al., 2005) for sampling the principal odour sources of seven Italian landfills in order to estimate an Odour Emission Factor (OEF). Sarkar et al. have used olfactometric analysis on samples from various sensitive areas of a municipal solid waste (MSW) landfill site to find a relationship between odour concentration and odour intensity (Sarkar \& Hobbs, 2002). Many authors have carried out odour measurement at landfills using more than one technique to characterize such complex plants; so dynamic olfactometry has been coupled with GC-MS analysis (Capelli et al., 2008; Pagè et al., 2008), electronic nose (Capelli et al., 2008; Li, 2003; Romain et al., 2008; Snidar et al., 2008), dispersion modelling (Li, 2003; Snidar et al., 2008), odour patrol monitoring (Li, 2003) and field determination (Romain et al., 2008).

\subsection{Chemical sensors}

The need of a more analytical approach to the quantitative measurement of odours has led to the use of chemical sensors. The response of the chemical sensors with partial selectivity is measured upon exposure of the sampled odour or multicomponent gas-mixture and the pattern based on the overall response of a sensors array defines a chemical fingerprint related to a given sampled odour. The recorded data of the sensors array response towards various odours can be usually processed by pattern recognition techniques (i.e., artificial neural networks, multivariate statistical analysis) for their classification, in order to identify an odour and quantify the concentration.

Chemical sensors are integrated with a sampling system and a signal processing unit to have an electronic nose (E-Nose), that is a device developed to reproduce the human olfactory system. An E-Nose requires a training for any specific application, but, on the other hand, it is a rapid and economic alternative to other techniques of odour measurement. The type of chemical sensors which can be used in an E-Nose need to be responsive to molecules in the gas phase. At present, there are two main types of gas sensor: metal oxide (MOX) and conducting polymer $(\mathrm{CP})$ resistive sensors.

Gas sensors, based on the chemical sensitivity of semiconducting metal oxides, are readily available commercially and have been more widely used to make arrays for odour measurement than any other single class of gas sensors. A deep overview on sensor materials for odour detection can be found in literature (Gopel et al., 1992; Sbreveglieri, 1992).

All chemical sensors comprise an appropriate and chemically-sensitive material interfaced to a transducer, hence, the solid-state sensors are essentially constituted by a chemically sensitive interface (sensitive material) and a transducer. The classification of chemical 
sensors can be realized on the basis of the transducer used: conductometric (resistive), optical, electrochemical, mechanical/acoustic or ultrasonic, thermal, MOSFET (metal-oxidesemiconductor field-effect transistor) (D'Amico \& Di Natale, 2001; D'Amico et al., 1995). A transduction process is realized by converting the input-event or measurand into an output electrical signal (analogue voltage or current, digital voltage) correlated to the measurand that generates it. The output electrical signal is properly conditioned, processed and stored for analysis.

Example of applications of chemical sensors for landfill monitoring.

Many multiparameter portable sensor-systems have been studied and exploited in field measurements for air quality control of toxic pollutants (NOx, $\mathrm{CO}, \mathrm{SO}_{2}, \mathrm{H}_{2} \mathrm{~S}$ ) (Al-Ali et al., 2010). Moreover, sensors arrays have been used for odour monitoring of landfill municipal sites and for odour quantification (Micone \& Guy, 2007; Nicolas et al., 2000; Persaud et al., 2005, 2008; Penza et al., 2010). Comini et al. have tested solid-state chemoresistive gas sensors based on mixed-oxides thin films to detect odourous compounds in gases produced by a landfill (Comini et al., 2004). Perera et al. implemented an electronic nose with a small computer to easily provide remote control of bad odours in landfill sites (Perera et al., 2001). Persaud et al. (Persaud et al., 2008) used a single-point E-Nose instrument for continuous monitoring of odours in the biogas produced by wastes fermentation along the perimeter of a municipal landfill site. Since landfills represent one of the major causes of odour complaints (Sironi et al., 2005) and a kind of plant difficult to monitor, because of the great variety of substances that may cause odour nuisance, the use of more than one technique for odour determination is required. For a complete characterization of odours, Capelli et al. have used olfactometry, chemical analyses with GC-MS and electronic noses, finding that even if the results of the three different odour characterization techniques do not necessarily correlate, each one contributes to solve the complexity of odour measurement in the environment (Capelli et al, 2008). Other comprehensive investigations on landfill areas used olfactometry in combination with: dispersion modelling, odour patrol monitoring and ENose (Li, 2003); dynamic olfactometry, field determination of odour perception points and electronic noses (Romain et al., 2008). Another approach was carried out using results of olfactometric analysis as input for a dispersion model and E-Noses for continuous monitoring to determine the landfill odour impact on a specific receptor (Snidar et al., 2008).

\section{A methodological approach for the definition of an odour guideline}

\subsection{Odour regulations: the principal approaches}

The odour emission regulation is generally tackled valuating two aspects:

- emissions, expressed as the odour concentration released by a particular source. In this case, two approaches have been adopted by the legislations of the different countries, establishing precise limits for the whole odour mixture and/or for single chemical compounds. In the first case, the odour concentration is expressed in odour units $\left(\mathrm{ou} / \mathrm{m}^{3}\right)$ and detected through dynamic olfactometry. In the second one only the concentrations of specific compounds are set, expressed in typical mass/volume units; the limits have been established based on odour thresholds rather than toxicological impacts (RWDI Air Inc., 2005). Such odour limits are related with compounds that have a typical odorous impact (e.g., ammonia, hydrogen sulphide, methyl mercaptans) (Nicell, 2009). 
Because of the wide range of odour industrial processes and sources (punctual or active/passive areal sources), the prescriptive limits for the odour mixtures usually refer to specific sources (above all punctual or active areal sources) and to precise plants (above all composting plants). In particular, for passive areal sources, such as dumps in landfills, it is extremely critical fixing limits, due to the variability of the amount of stored materials and of the area extension.

- odour impact criteria, defined as odour concentration limits considered acceptable for avoiding odour annoyance at receptors. They are typically expressed in terms of a concentration (i.e., in ou $/ \mathrm{m}^{3}$ ) considering an averaging time and a frequency of exposure (e.g., 98 th percentile of hourly average concentrations in one year). Odour concentrations at receptors are estimated using appropriate dispersion models, that determine whether the emissions are in compliance with odour impact criteria. These limits have a predictive nature and establish very low odour concentrations that are not detectable by available measurement methodologies.

Both the aspects present some limitations, such as the difficulty of assigning an emission limit because of the wide range of odour sources and/or the complexity of choosing the opportune parameters for models. So, it seems necessary to consider an integrated approach in order to overcome these drawbacks.

\subsection{An approach for an odour guideline}

The actual approaches for odour regulation do not adequately satisfy the requests of monitoring and control expressed by the population directly exposed.

In this section, a proposal of an odour guideline is presented with the purpose of defining acceptability and monitoring criteria for odour emissions produced by landfills.

According to the principle of pollutant prevention and reduction, commonly adopted by environmental legislations, the present methodology suggests a coupling between a predictive approach, based on dispersion models, and a systematic approach to carry out the monitoring and the control through reliable methodologies.

The acceptability criteria, resulting from the odour guideline proposal, will be verified and applied taking into account the background values detected on the territory. Such background levels could be assessed by means of ad hoc measurements (in appropriate meteorological conditions or when sources are not active) carried out by dynamic olfactometry. In particularly complex cases, such as co-presence of other significant odour sources, this evaluation could be executed through chemical characterization of ambient air samples. In addition, depending on the plant odour impact, an appropriate continuous monitoring system should be planned in order to perform a processes control.

The focus of the proposal consists in the implementation of two approaches for the authorization of odour emissions:

- $\quad$ assessment of acceptability criteria using predictive methods;

- $\quad$ the buffer zone approach.

\subsubsection{Assessment of acceptability criteria $(Y)$ using predictive methods}

This approach employs the use of mathematical models to predict the downwind odour concentrations at receptors on the basis of odour emission rates, topography and meteorological data referred to a selected period of time. Such models aim to determine whether the estimated emissions at sensitive receptors are in compliance with ambient air 
quality criteria, considered acceptable for the exposure of the population. These criteria, named $Y$, can be defined on the basis of several parameters, such as:

- $\quad$ presence of sensitive receptors;

- distance between the plant and sensitive receptors;

- $\quad$ land use (residential, commercial, agricultural, industrial);

- $\quad$ existing or new plants;

- distribution of concentration values expressed as percentiles;

- $\quad$ averaged time considered for simulations.

So, $\mathrm{Y}$ is set as a specific percentile value related to an averaging time calculated through dispersion models.

For example, assuming that $\mathrm{Y}$ is equal to $2 \mathrm{ou} / \mathrm{m}^{3}$ as $98^{\text {th }}$ percentile of hourly average concentrations in one year at the first receptor, figure 1 and figure 2 illustrate modelling simulations executed for a landfill. In figure 1 the receptor is situated in an area where the predicted odour concentration is lower than $2 \mathrm{ou} / \mathrm{m}^{3}$, so the $\mathrm{Y}$ limit is fulfilled; on the contrary, figure 2 shows the case in which $\mathrm{Y}$ is not attained at the receptor.
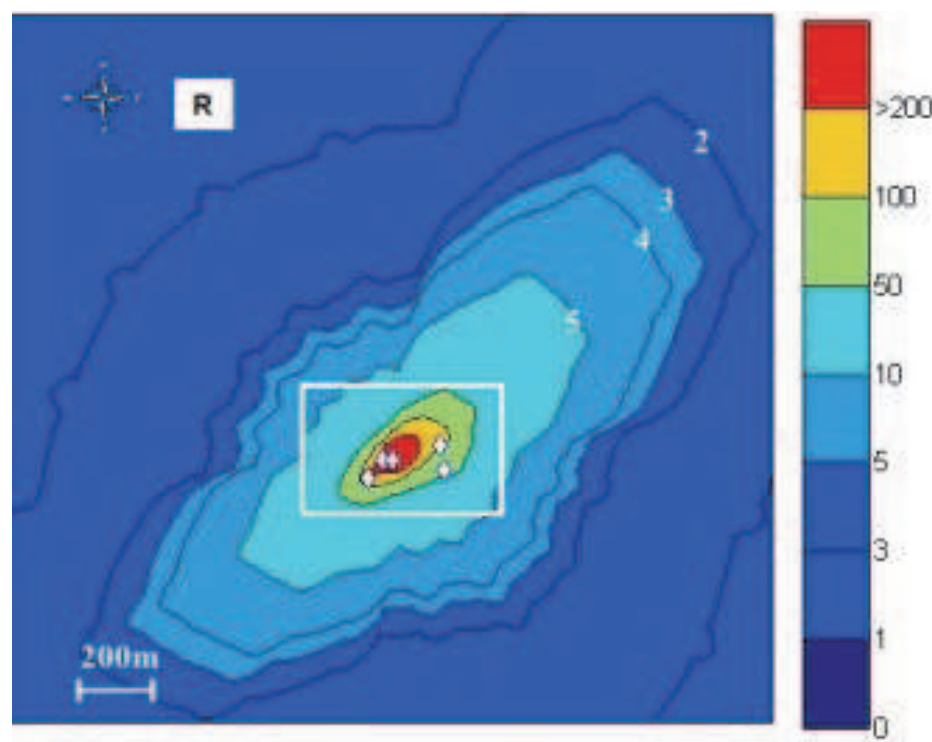

Fig. 1. Map showing $Y_{\text {predicted }}$ in compliance with $Y_{\text {limit. }}$ The white rectangle delimits the landfill perimeter; the white points inside the plant represent the odour sources. $\mathrm{R}$ indicates the position of the receptor.

According to the ratio between the limit value and the predicted one ( $\left.\mathrm{Y}_{\text {predicted }} / \mathrm{Y}_{\text {limit }}\right)$, the implementation of continuous monitoring systems should be planned in order to perform a process control, at the boundaries of the plant and/or at the sensitive receptors, useful for identifying critical phases, under different meteorological conditions. Figure 3 shows the case in which, at receptor, the ratio between $Y_{\text {predicted }}$ and $Y_{\text {limit }}$ is greater than an acceptable value (e.g. 0.80). The figure illustrates the implementation of three monitoring systems, positioned at the plant perimeter, according to the predominant wind directions, and at the receptor. 
The output data of sensors or analyzers used for continuous monitoring must show a correlation with odour concentration, expressed in odour units.

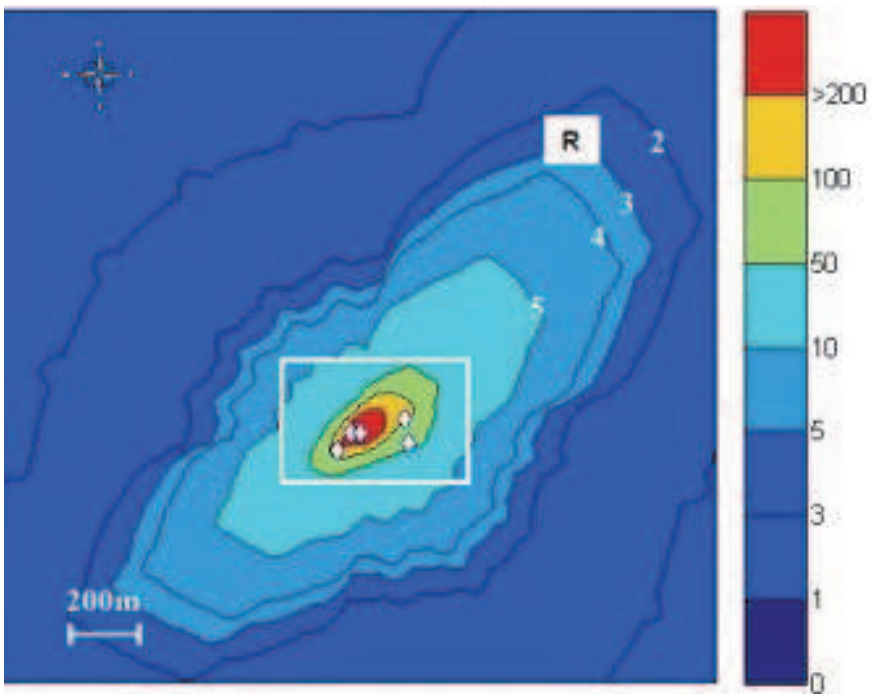

Fig. 2. Map showing $Y_{\text {predicted }}$ not in compliance with $Y_{\text {limit. }}$ The white rectangle delimits the landfill perimeter; the white points inside the plant represent the odour sources. $\mathrm{R}$ indicates the position of the receptor.
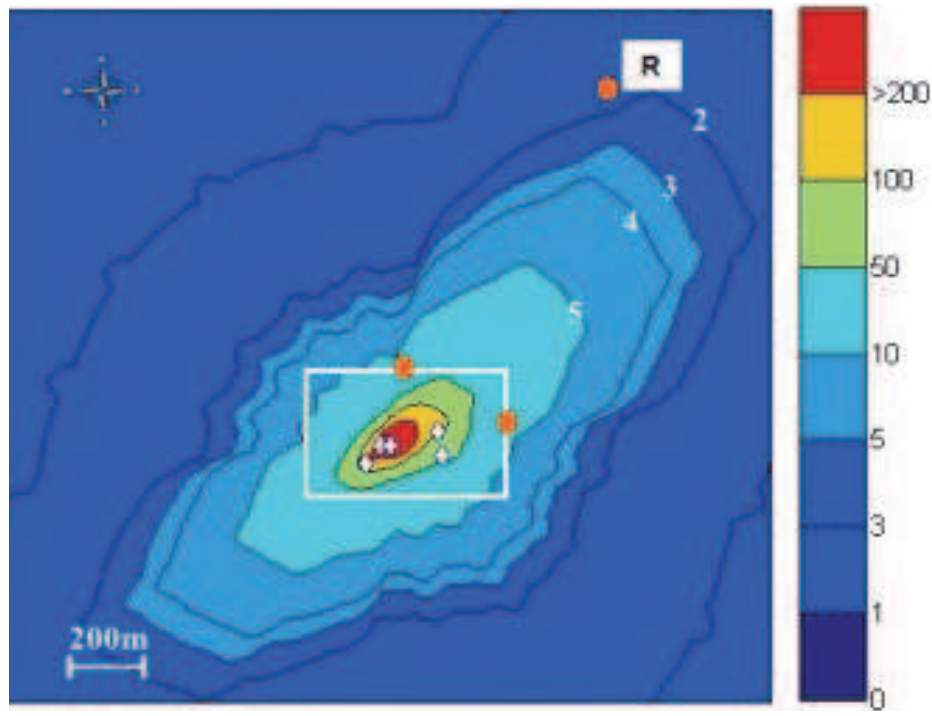

Fig. 3. Individuation of continuous monitoring points. The white rectangle delimits the landfill perimeter; the white points inside the plant represent the odour sources. $R$ indicates the position of the receptor. The red circles represent the continuous monitoring systems. 


\subsubsection{The buffer zone approach $(Z)$}

The buffer zone identifies an area around the plant boundaries, outside of which a prescriptive limit, named $Z$, expressed in odour units and detectable through dynamic olfactometry, must never be exceeded. Furthermore, in the area between the plant perimeter and the buffer zone boundaries a maximum concentration value, named $X$, must never be exceeded. The buffer zone can have a more or less regular shape, individuated according to the predominant wind directions, the presence of receptors and the geographic location. The buffer zone extension can be defined using dispersion models based on the meteorological scenarios that have determined the worst odour dispersion conditions in a defined period of time. These scenarios have to be described so that a possible exceeding, determined by a meteorological situation worse than those previously considered, could be permitted. If the $\mathrm{Z}$ limit is fulfilled inside the plant boundaries, the buffer zone overlaps with the plant perimeter.

Figure 4 and figure 5 explain how the buffer zone is defined according to the worst scenarios. For example, if $\mathrm{Z}$ is equal to $50 \mathrm{ou} / \mathrm{m}^{3}$, the buffer zone must comprehend the area where $50 \mathrm{ou} / \mathrm{m}^{3}$ are overcome in the worst meteorological conditions. In figure 4 (case 1 ) the buffer zone is outside the plant perimeter, while in figure 5 (case 2) overlaps with it. In this last case, the $Z$ value must be applied and verified at the plant perimeter.
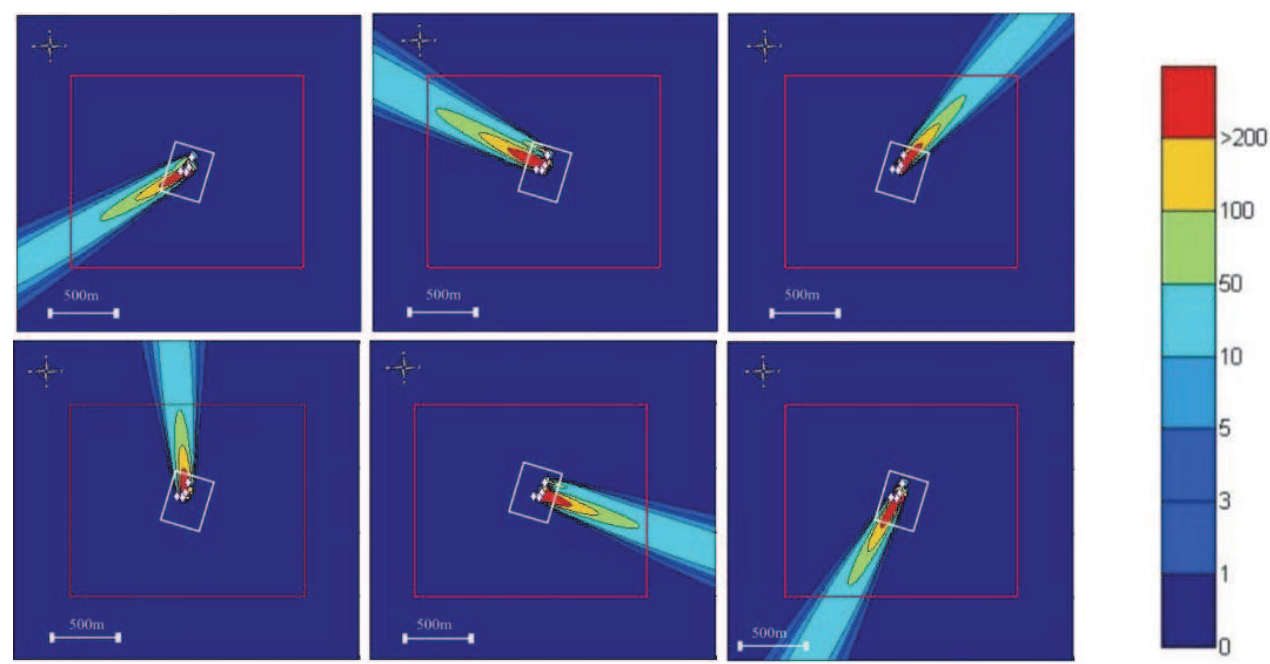

Fig. 4. Maps illustrating the individuation of the buffer zone considering the worst odour dispersion conditions for a landfill (case 1). The white rectangle delimits the plant perimeter while the red one individuates the buffer zone perimeter; the white points are the odour sources. In all maps, the buffer zone is defined on the bases of the isoline of $50 \mathrm{ou} / \mathrm{m}^{3}$.

The definition of a buffer zone is a valid approach particularly for landfills that present areal emissions, usually located in ground-line; in fact, in this type of emissions the odour concentration decreases moving away from the sources. $Z$ and $X$ values must be verified by means of olfactometric measurements of ambient air samples. For this purpose, a monitoring plan should be proposed and verified. An example of monitoring plan is presented in Figure 6 where the six sampling points, located at the buffer zone perimeter, 
have been chosen upwind and downwind according to the predominant wind direction detected during the sampling. The other sampling points within the buffer zone have been located moving away from the plant boundaries along the predominant wind direction.
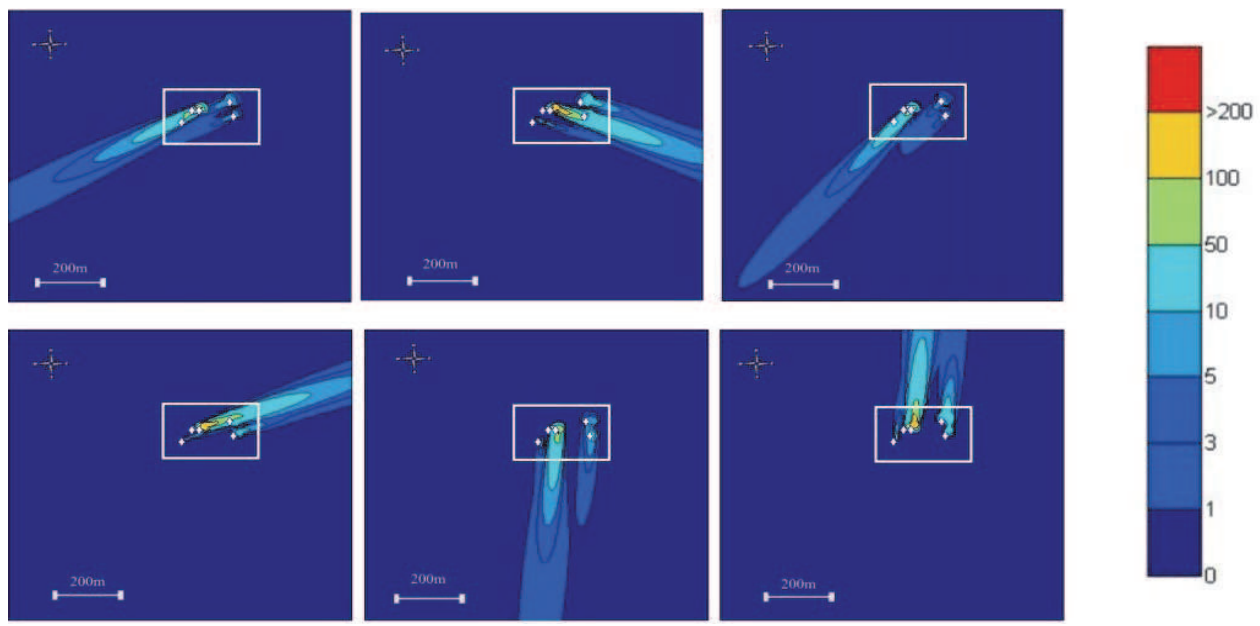

Fig. 5. Maps illustrating the individuation of the buffer zone considering the worst odour dispersion conditions for a landfill (case 2). The white rectangle delimits the plant perimeter; the white points are the odour sources. In all maps, since the isoline of $50 \mathrm{ou} / \mathrm{m}^{3}$ falls within the plant perimeter, the buffer zone overlaps with the plant boundaries.

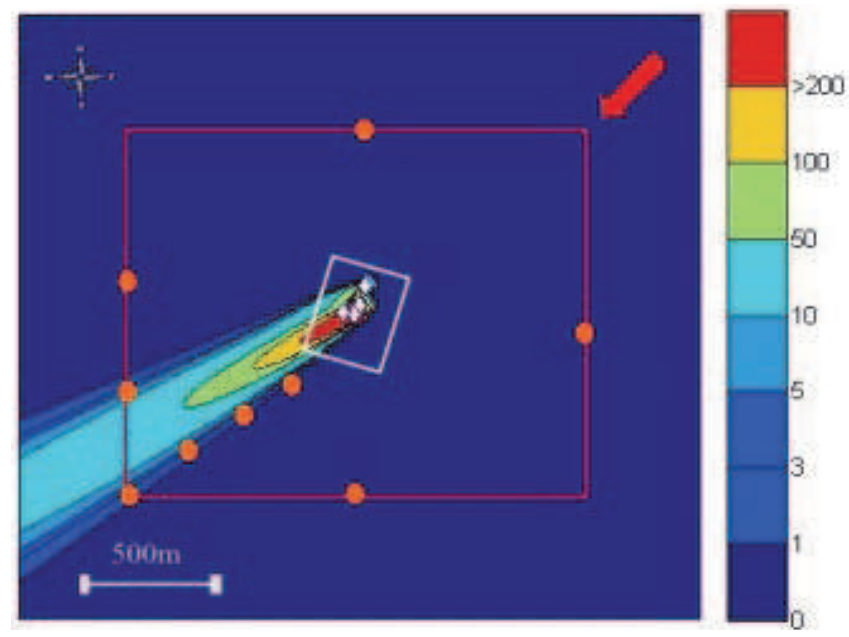

Fig. 6. An example of a monitoring plan. The white rectangle delimits the plant perimeter while the red one individuates the buffer zone perimeter. The red arrow shows the predominat wind direction; the orange circles indicate the location of the sampling points.

As described for $\mathrm{Y}$ limit, the implementation of continuous monitoring systems can be planned in relation to the extension of the buffer zone and the presence of receptors inside 
or near it. According to the different conditions, these systems can be situated at the receptors and/or at the boundaries of the buffer zone and of the plant.

Figure 7 shows an example for the localization of the monitoring systems; in this case the systems have been positioned at the receptors and at the boundaries of the buffer zone considering the predominant wind directions.

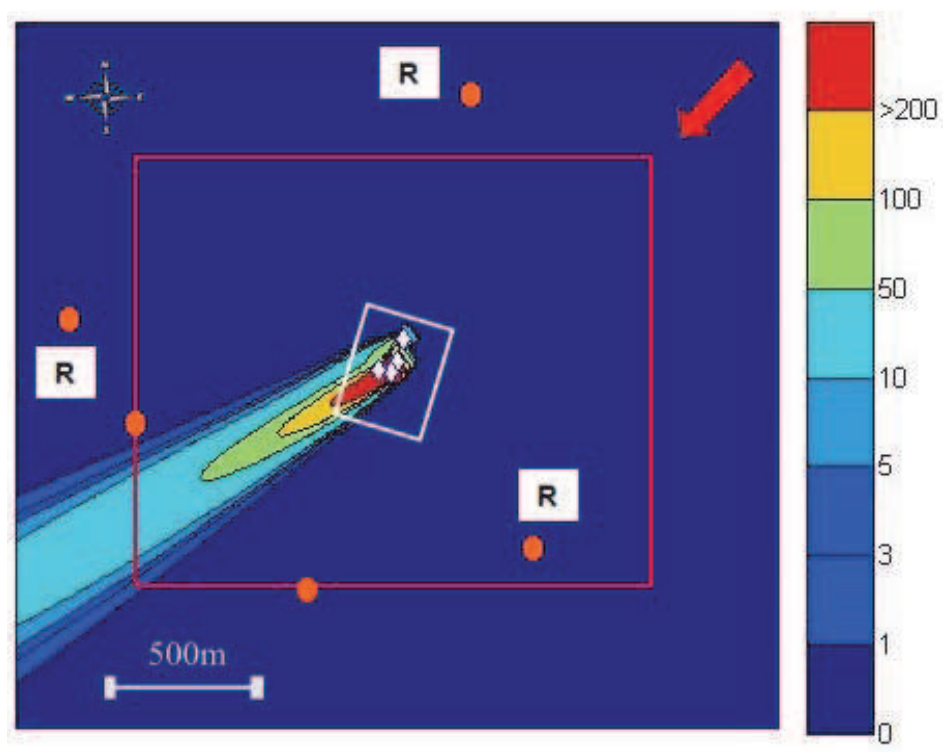

Fig. 7. An example of the localization of continuous monitoring points. The white rectangle delimits the plant perimeter while the red one individuates the buffer zone perimeter. The red arrow shows the predominat wind direction; the orange circles indicate the continuous monitoring systems. $\mathrm{R}$ indicates the position of the receptors.

\section{Conclusions}

The increasing attention of the population to olfactory nuisance and the proximity of industrial plants to residential areas have created the need of evaluating odour impact and regulating odour monitoring and control. Nowadays the adopted regulations do not adequately satisfy the requests of monitoring and control expressed by the population directly exposed.

In this paper, a proposal of a guideline for assessing landfill odour impact has been described; the guideline integrates a predictive approach based on dispersion models and a systematic approach to carry out the monitoring and the control. The novelty of the proposal is represented by the introduction of a buffer zone, individuated by means of dispersion models, in which prescriptive limits have to be fulfilled and verified by standard measurement methodologies. In addition, the odour guideline recommends to perform a process control for particularly impactful plants, realized through continuous monitoring systems. This methodological approach can be easily adopted even for the regulation of other industrial activities that cause odour emissions. 


\section{References}

Al-Ali, A.R.; Zualkernan, I. \& Aloul, F. (2010). A mobile GPRS-sensors array for air pollution monitoring. IEEE Sensors Journal, Vol. 10, No. 10, (2010), pp. 1666-1671, ISSN 1530437X

Allen, M.R.; Braithwaite, A. \& Hills, C.C. (1997). Trace organic compounds in landfill gas at seven U.K. waste disposal sites. Environmental Science Technology, Vol. 31, No. 4, (March, 1997), pp. 1054-1061, ISSN 0013-936X

AS/NZS (2001) 4323.3:2001 Australian/New Zealand Standard ${ }^{\mathrm{TM}}$ Stationary source emissions Part 3: Determination of odour concentration by dynamic olfactometry, Jointly published by Standards Australia International Ltd, GPO Box 5420, Sydney, NSW

ASTM (2004). ASTM E679-04: Standard Practice for Determination of Odor and Taste Thresholds by a Forced-Choice Ascending Concentration Series Method of Limits. American Society for Testing and Materials, Philadelphia, PA

Best, P.R.; Lunney, K.E. \& Killip, C.A. (2001). Statistical elements of predicting the impact of a variety of odour sources. Water Science and Technology, Vol. 44, No. 9, pp. 157-164, ISSN 1606-9749

Bockreis, A. \& Steinberg, I. (2005). Measurement of odour with focus on sampling techniques. Waste Management, Vol. 25, No. 9, (2005), pp. 859-863, ISSN 0956-053X

Bracci, G.; Paci, B. \& Giardi, M. (1995). Paper mill sludge used a daily cover in landfills, Proceedings of Fifth International Landfill Symposium, pp. 897-904, S. Margherita di Pula- Cagliari, Italy, 2-6 October, 1995

Bradley, A.D.; Cook, D.J.; Edwards, J.S.; Johnston, A.G.; Linforth, R.S. \& Taylor, A.J. (2001). The control and measurement of landfill odours, Proceedings of Eighth International Landfill Symposium, pp. 681-690, S. Margherita di Pula - Cagliari, Italy, 1-5 October 2001

Bruno, P.; Caselli, M.; de Gennaro, G.; Solito, M. \& Tutino, M. (2007). Monitoring of odor compounds produced by solid waste treatment plants with diffusive samplers. Waste Management, Vol. 27, No. 4, (2007), pp. 539-544, ISSN 0956-053X

Camel, V. \& Caude, M. (1995). Trace enrichment methods for the determination of organic pollutants in ambient air. Journal of Chromatography A, Vol. 710, No. 1, (August 1995), pp. 3-19, ISSN 0021-9673

Capelli, L.; Sironi, S.; Del Rosso, R.; Cèntola, P. \& Il Grande, M. (2008). A comparative and critical evaluation of odour assessment methods on a landfill site. Atmospheric Environment, Vol. 42, No. 30, (September 2008), pp. 7050-7058, ISSN 1352-2310

Capelli, L.; Sironi, S.; Del Rosso, R.; Cèntola, P.; Pierucci, S.; Austeri, C. \& Rossi A. (2010). Assessment of the odour impact of the industrial area of Terni(Italy). Chemical Engineering Transactions, Vol. 23, pp. 261-266, ISBN 978-88-95608-14-3

Carson, D.A. (1992). Municipal solid waste landfill daily cover alternatives. Geotextiles and Geomembranes, Vol. 11, No. 4-6, pp. 629-635, ISSN 0266-1144

CEN (Committee for European Normalization) EN13725 (2003): Air Quality -Determination of Odour Concentration by Dynamic Olfactometry, Brussels, Belgium

Comini, E.; Guidi, V.; Ferroni, M. \& Sberveglieri, G. (2004). TiO2:Mo, MoO3:Ti, TiO + WO3 and TiO:W layer for landfill produced gases sensing. Sensors and Actuators B, Vol. 100, No. 1-2, (June 2004), pp. 41-46, ISSN 0925- 4005 
Chemel, C.; Riesenmey, C.; Chollet, J.P. \& Batton-Hubert, M. (2005). Influence of the topography on odour dispersion from a landfill located in complex terrain, 5th annual Meeting of the european meteorological society, Utrecht - NL, September 2005

Chen, Y.C.; Bundy, D.S. \& Hoff, S. (1998). Development of a Model of Dispersion Parameters for Odour Transmission from Agricultural Sources, Journal of agricultural Engineering Research, Vol. 69, No. 3, (March 1998), pp. 229-238, ISSN 0021-8634

Craven, M.A.; Gardner, J.W. \& Bartlett, P.N. (1996). Electronic noses - development and future prospects. Trends in Analytical Chemistry, Vol. 15, No. 9, (October, 1996), pp. 486 - 493, ISSN 0165-9936

D'Amico, A. \& Di Natale, C. (2001). A contribution on some basic definitions of sensors properties. IEEE Sensors Journal, Vol. 1, No. 3, (2001), pp. 183-190, ISSN 1530-437X

D'Amico, A.; Di Natale, C. \& Taroni, A. (1995) Sensors Parameters in Sensors for domestic applications. Proceedings of the First European School on Sensors (ESS'94), Lecce Italy, September 1994

Dalton, P. (2003). Upper airway irritation, odor perception and health risk due to airborne chemicals. Toxicology Letters, Vol. 140-141, (April, 2003), pp. 239-248, ISSN 03784274

Davoli, E.; Gangai, M.L.; Morselli, L. \& Tonelli, D. (2003). Characterisation of odorants emissions from landfills by SPME and GC/MS. Chemosphere, Vol. 51, No. 5, (May, 2003), pp. 357-368, ISSN 0045-6535

Demeestere, K.; Dewulf, J.; De Roo, K.; De Wispelaere, P. \& Van Langenhove, H. (2008). Quality control in quantification of volatile organic compounds analysed by thermal desorption-gas chromatography-mass spectrometry. Journal of Chromatography A, Vol. 1186, No. 1-2, (April 2008), pp. 348-357, ISSN 0021-9673

Demeestere, K.; Dewulf, J.; De Witte, B. \& Van Langenhove, H. (2007). Review: Sample preparation for the analysis of volatile organic compounds in air and water matrices. Journal of Chromatography A, Vol. 1153, No. 1-2, (June 2007), pp. 130-144, ISSN 0021-9673

Di Francesco, F.; Lazzerini, B.; Marcelloni, F. \& Pioggia, G. (2001). An electronic nose for odour annoyance assessment. Atmospheric Environment, Vol. 35, No. 7, pp. 1225 123, ISSN 1352-2310

Dincer, F. \& Muezzinoglu, A. (2006). Chemical characterization of odors due to some industrial and urban facilities in Izmir, Turkey. Atmospheric Environment, Vol. 40, No. 22, (July 2006), pp. 4210-4219, ISSN 1352-2310

Dincer, F.; Odabasi, M. \& Muezzinoglu, A. (2006). Chemical characterization of odorous gases at a landfill site by gas chromatography-mass spectrometry. Journal of Chromatography A, Vol. 1122, No. 1-2, (July, 2006), pp. 222-229, ISSN 0021-9673

Drew, G.H.; Smith, R.; Gerard, V.; Burge, C.; Lowe, M.; Kinnersley, R.; Sneath, R. \& Longhurst, P.J. (2007). Appropriateness of selecting different averaging times for modelling chronic and acute exposure to environmental odours. Atmospheric Environment, Vol. 41, No. 13, (April, 2007), pp. 2870-2880, ISSN 1352-2310

Dupont, S.; Brunet, Y. \& Jarosz, N. (2006). Eulerian modelling of pollen dispersal over heterogeneous vegetation canopies, Agricultural and Forest Meteorology, Vol. 141, No. 2-4, (December 2006), pp. 82-104, ISSN 0168-1923 
ElFadel, M.; Findikakis, A.N. \& Leckie, J.O. (1997). Environmental impacts of solid waste landfilling. Journal of Environmental Management, Vol. 50, No. 1, (May, 1997), pp. 125, ISSN 0301-4797

Frechen, F.B. (1994). Odour emissions of wastewater treatment plants: recent German experiences. Water Science and Technology. Vol. 30, No. 4, (1994), pp. 35 - 46, ISSN 0273-1223

Freeman, J.W. (1991). The physiology of perception. Scientific American, Vol. 264, (February, 1991), pp. $78-85$

Friedrich, J.E. \& Acree, T.E. (1998). Gas Chromatography Olfactometry (GC/O) of Dairy Product. International Dairy Journal, Vol. 8, No. 3 (March, 1998), pp. 235-241, ISSN 0958-6946

Gardner, J.W. \& Bartlett, P.N. (1994). A brief history of electronic noses. Sensors and Actuators B, Vol. 18-19, pp. 211-220, ISSN 0925- 4005

Gawrys, M.; Fastyn, P.; Gawlowski, J.; Gierczak, T. \& Niedzielski, J. (2001).Prevention of water vapour adsorption by carbon molecular sieves in sampling humid gases. Journal of Chromatography A, Vol. 933, No. 1-2, (November 2001), pp. 107-116, ISSN 0021-9673

GOAA (1999). Guideline on odour in ambient air - Determination and Assessment of Odour in Ambient Air (1994). (Feststellung und Beurteilung von GeruchsimmissionenGeruchsimmiions-Richtlinie) Länderausschuss für Immissionsschutz, LAISchriftenreihe No. 5, Berlin; revised version 1999 (available in English)

Gopel, W.; Jones, T.A.; Kleitz, M.; Lundstrom, I. \& Seiyama, T. (Eds.).(1992). Sensors - A comprehensive Survey - Chemical and Biochemical Sensors, Part I-II, Vol. 2-3, VCH, ISBN 978-3-527-62057-9, Weinheim

Gorecki, T. \& Namiesnik, J. (2002). Passive sampling. Trends in analytical chemistry, Vol. 21, No. 4, (April 2002), pp. 276-291, ISSN 0165-9936

Hancock, J.S.; Newman, S.J. \& Chadwick, B.R. (1999). Mulched woody material mixtures: an improved performance daily cover, Proceedings of Seventh International Landfill Symposium, pp. 365-372, S. Margherita di Pula - Cagliari, Italy, 4-8 October 1999

Harper, M. (2000). Review: Sorbent trapping of volatile organic compounds from air. Journal of Chromatography A, Vol. 885, No. 1-2, (July 2000), pp 129-151, ISSN 0021-9673

Hayes, E.T.; Curran, T.P. \& Dodd, V.A. (2006). A dispersion modelling approach to determine the odour impact of intensive poultry production units in Ireland. Bioresource Technology, Vol. 97, No. 15, (October, 1996), pp. 1773-1779, ISSN 09608524

Holmes, N.S. \& Morawska, L. (2006). A review of dispersion modelling and its application to the dispersion of particles: An overview of different dispersion models available. Atmospheric Environment, Vol. 40, No. 30, (September 2006), pp. 5902-5928, ISSN $1352-2310$

Hurst, C.; Longhurst, P.; Pollard, S.; Smith, R.; Jefferson, B. \& Gronow, J. (2005). Assessment of municipal waste compost as a daily cover material for odour control at landfill sites. Environmental Pollution, Vol. 135, No. 1, (May, 2005), pp. 171-177, ISSN 02697491

Irish Environmental Protection Agency. (2001). Odour Impacts and Odour Emission Control Measures for Intensive Agriculture. RED Report Series No. 14. OdourNet UK Ltd, Bath 
Kaufmann, A.; Simonin, O.; Helie, J. \& Cuenot, B. (2003). Dynamics and dispersion in 3D unsteady Eulerian-Eulerian simulations of twophase flows. In: International Conference on Supercomputing in Nuclear Applications, Palais des Congrès, Paris, France, 2003

Koe, L.C.C. (1989). Sewage odors quantification, In: Encyclopedia of Environmental Control Technology, Wastewater Treatment Technology, Cheremisinoff, P.N., pp. 423-446, Gulf Publishing Company, ISBN 0872012476, Houston, USA

Kumar, A. \& Víden, I. (2007). Volatile Organic Compounds: Sampling Methods and Their Worldwide Profile in Ambient Air. Environmental Monitoring and Assessment, Vol.131, No. 1-3, (August 2007), pp. 301-321, ISSN 0167-6369

Leach, J. Blanch, A. \& Bianchi A.C. (1999). Volatile organic compounds in an urban airborne environment adjacent to a municipal incinerator, waste collection centre and sewage treatment plant. Atmospheric Environment, Vol. 33, No. 26, (November 1999), pp. 4309-4325, ISSN 1352-2310

Li, X. (2003). Odour impact and control at a landfill site in Hong Kong, East Asia workshop on odour measurement and control review. Ministry of the Environment, Japan, pp. 78-86

Lo, Y.C.M.; Koziel, J.A.; Cai, L.; Hoff, S.J.; Jenks, W.S. \& Xin, H. (2008). Simultaneous Chemical and Sensory Characterization of Volatile Organic Compounds and SemiVolatile Organic Compounds Emitted from Swine Manure using Solid Phase Microextraction and Multidimensional Gas Chromatography-Mass SpectrometryOlfactometry. Journal of Environmental Quality, Vol. 37, No. 2, (March 2008), pp. 521534, ISSN 0047-2425

Mahin, T.D. (2001). Comparison of different approaches used to regulate odours around the world. Water Science and Technology, Vol. 44, 9, pp. 87-102, ISSN 1606-9749

Matisová, E. \& Škrabáková, S. (1995). Carbon sorbents and their utilization for the preconcentration of organic pollutants in environmental samples. Journal of Chromatography A, Vol. 707, No. 2, (July 1995), pp. (145-179, ISSN 0021-9673

Mc Cartney, H.A. \& Fitt, B.D. (1985). Construction of dispersal models, In: Advances in Plant Pathology: Mathematical Modelling of Crop Diseases, Vol 3, Gilligan, C.A. (Ed.), pp. 147-153, Academic Press, London

Micone, P.G. \& Guy, C. (2007). Odour quantification by a sensor array: An application to landfill gas odours from two different municipal waste treatment works. Sensors and Actuators B, Vol. 120, No. 2, (January 2007), pp. 628-637, ISSN 0925-4005

Mussio, P.; Gnyp, A.W. \& Henshaw, P.F. (2001). A fluctuating plume dispersion model for the prediction of odour-impact frequencies from continuous stationary sources. Atmospheric Environment, Vol. 35, No. 16, (June, 2001), pp. 2955-2962, ISSN 13522310

Nicell, J.A. (2009). Assessment and regulation of odour impacts. Atmospheric Environment, Vol. 43, No. 1, (January, 2009), pp. 196 - 206, ISSN 1352-2310

Nicolas, J.; Romain, A.C.; Wiertz, V.; Maternova, J. \& Andre, P. (2000). Using the classification model of an electronic nose to assign unknown malodours to environmental sources and to monitor them continuously. Sensors and Actuators B, Vol. 69, No. 3, (October, 2000), pp 366-371, ISSN 0925-4005

Pagè, T.; Narjoux, A.; Guy, C.; Caron, R.F. \& Fècil, B. (2008). Odours \& Voc impact Evaluation Of Three Categories of Landfills, Chemical Engineering Transactions, Vol. 15, pp. 135-142, ISBN 978-88-95608-09-9 
Pearce, T.C. (1997). Computational parallel between the biological olfactory pathway and its analogue 'The electronic nose': Part I. Biological olfaction. BioSystems, Vol. 41, No. 1, (January, 1997), pp. 43-67, ISSN 1537-5110

Penza, M.; Rossi, R.; Alvisi, M.; \& Serra, E. (2010). Metal-modified and vertically-aligned carbon nanotube sensors array for landfill gas monitoring applications. Nanotechnology, Vol. 21, No. 10, (March 2010), 21, pp. 105501 (14 p.), ISSN 1361-6528

Perera, A.; Pardo, T.; Šundiæ, T.; Gutierrez-Osuna, R.; Marco, S. \& Nicolas, J. (2001). IpNose: Electronic nose for remote bad odour monitoring system in landfill sites, Proceedings of the 8th conference Eurodeur, Paris, June 2001, pp. 19-21

Peris, M. \& Escuder-Gilabert, L. (2009). A 21st century technique for food control: Electronic noses. Analytica Chimica Acta, Vol. 638, No. 1, (April, 2009), pp. 1-15, ISSN 00032670

Persaud, K.C.; Wareham, P.; Pisanelli, A.M. \& Scorsone, E. (2005). Electronic Nose - New condition monitoring devices for environmental applications. Chemical Senses, Vol. 30, No. 1,(2005), pp. 252-253, ISSN $0379864 X$

Persaud, K.C.; Woodyan, N.C.P. \& Sneath, R.W. (2008). Development of a perimeter odor monitoring system for landfill sites. Proceedings of IEEE Sensors 2008 Conference, Lecce, Italy, pp. 1360-1363

Ras, M.R.; Borrull, F. \& Marce, R.M. (2009). Sampling and preconcentration techniques for determination of volatile organic compounds in air samples. Trends in Analytical Chemistry, Vol. 28, No. 3, (March 2009), pp. 347-361, ISSN 0165-9936

Ras-Mallorquì, M.R.; Marcè-Recasens, R.M. \& Borrull-Ballarìn, F. (2007). Determination of volatile organic compounds in urban and industrial air from Tarragona by thermal desorption and gas chromatography-mass spectrometry. Talanta, Vol. 72, No. 3, (May 2007), pp. 941-950, ISSN 0039-9140

Ribes, A.; Carrera, G.; Gallego, E.; Roca, X.; Berenguer, M.J. \& Guardino, X. (2007). Development and validation of a method for air-quality and nuisance odors monitoring of volatile organic compounds using multi-sorbent adsorption and gas chromatography/mass spectrometry thermal desorption system. Journal of Chromatography A, Vol. 1140, No. 1-2, (January 2007), pp. 44-55, ISSN 0021-9673

Romain, A.C.; Delva, J. \& Nicolas, J. (2008). Complementary approaches to measure environmental odours emitted by landfill areas. Sensors and Actuators B, Vol. 131, No. 1, (April 2008), pp. 18-23, ISSN 0925-4005

Rosenkranz, H.S. \& Cunningham, A.R. (2003). Environmental odor and health hazards. The Science of the Total Environment, Vol. 313, (September, 2003), pp. 15 -24, ISSN 00489697

RWDI Air Inc. (2005). Odour Management in British Columbia: Review and Recommendations. Final Report to the Ministry of Water, Land and Air Protection, BC

Sarkar, U. \& Hobbs, E. (2002). Odour from municipal solid waste (MSW) landfills: A study on the analysis of perception, Environment International, Vol. 27, No. 8, (March 2002), pp. 655-662, ISSN 01604120

Sarkar, U.; Hobbs, S.E. \& Longhurst, P. (2003). Dispersion of odour: a case study with a municipal solid waste landfill site in North London, United Kingdom. Journal of Environmental Management, Vol. 68, No. 2, (June 2003), pp. 153-160, ISSN 0301-4797

Sberveglieri, G. (Ed.). (1992). Gas Sensors, Kluwer Academic, Dordrecht 
Scaglia, B. \& Adani, F. (2008). An index for quantifying the aerobic reactivity of municipal solid wastes and derived waste products. Science of the Total Environment, Vol. 394, No. 1, (May, 2008), pp. 183-191, ISSN 0048-9697

Scaglia, B.; Confalonieri, R.; D’Imporzano, G. \& Adani, F. (2010). Estimating biogas production of biologically treated municipal solid waste. Bioresource Technology, Vol. 101, No. 3, (February, 2010), pp. 945-952, ISSN 0960-8524

Scaglia, B.; Orzi, V.; Artola, A.; Font, X.; Davoli, E.; Sanchez, A. \& Adani, F. (2011). Odours and volatile organic compounds emitted from municipal solid waste at different stage of decomposition and relationship with biological stability. Bioresource Technology, Vol. 102, No. 6, (April, 2011), pp. 4638-4645, ISSN 0960-8524

Schauberger, G.; Piringer, M. \& Petz, E. (2002). Calculating Direction-dependent Separation Distance by a Dispersion Model to avoid Livestock Odour Annoyance. Biosystems Engineering, Vol. 82, No. 1, (May, 2002), pp. 25-37, ISSN 1537-5110

Schiffman, S.S. (1998). Livestock odors: implications for human health and well-being. Journal of Animal Science, Vol. 76, pp. 1343 - 1355, ISSN 0021-8812

Schulz,T.J. \& van Harreveld, A.P. (1996). International moves towards standardisation of odour measurement using olfactometry. Water Science and Technology, Vol. 34, No. 3-4, (1996), pp. 541-547, ISSN 0273-1223

Seethapathy, S.; Gorecki, T. \& Li, X. (2008). Passive sampling in environmental analysis. Journal of Chromatography A, Vol. 1184, No. 1-2, (March 2008), pp. 234-253, ISSN 0021-9673

Shimaoka, T.; Miyawaki, K.; Hanashima, M.; Tsuji, H. \& Ito, H. (1997). Impact of daily cover soil on the stabilisation of a landfill, Proceedings of Sixth International Landfill Symposium, pp. 341-350, S. Margherita di Pula - Cagliari, Italy, 13-17 October 1999

Sironi, S.; Capelli, L.; Cèntola, P.; Del Rosso, R. \& Il Grande, M. (2005). Odour emission factors for assessment and prediction of Italian MSW landfills odour impact. Atmospheric Environment, Vol. 39, No. 29, (September 2005), pp. 5387-5394, ISSN 1352-2310

Sironi, S.; Capelli, L.; Cèntola, P.; Del Rosso, R. \& Pierucci, S. (2010). Odour impact assessment by means of dynamic olfactometry, dispersion modelling and social participation. Atmospheric Environment, Vol. 44, No. 3, (January 2010), pp. 354-360, ISSN 1352-2310

Snidar, R.; Culòs, B.; Trovarelli, A.; Soldati, A.; Sironi, S. \& Capelli, L. (2008). Evaluation of odour emissions from a landfill through dynamic olfactometry, dispersion modelling and electronic noses. Chemical Engineering Transactions, Vol. 15, pp. 315322, ISBN 978-88-95608-09-9

Snopok, B.A. \& Kruglenko, I.V. (2002). Multisensor systems for chemical analysis: state-ofthe-art in Electronic Nose technology and new trends in machine olfaction. Thin Solid Films, Vol. 418, No. 1, (October, 2002), pp. 21-41, ISSN 0040-6090

Stevens, S.S. (1960). The Psychophysics of Sensory Functions. American Scientist, Vol. 48, (1960), pp. 226-253, ISSN 0003-0996

Stohl, A. \& Thomson, D.J. (1999). A Density Correction for Lagrangian Particle Dispersion Models. Boundary-Layer Meteorology, Vol. 90, No. 1, (January 1999), pp. 155-167, ISSN 0006-8314 
Stohl, A.; Hittenberger, M. \& Wotawa, G. (1998). Validation of the Lagrangian particle dispersion model flexpart against large-scale tracer experiment data. Atmospheric Environment, Vol. 32, No. 24, (October 1998), pp. 4245-4264, ISSN 1352-2310

Stuetz, R. \& Frechen, F.B. (Ed(s).). (2001). Odours in Wastewater treatment: Measurement, Modelling and Control, IWA Publishing, ISBN 1900222469, London, UK

Vincent, A. \& Hobson, J. (1998). Odour Control. Published for CIWEM by Terence Dalton Publishing Ltd., U.K.

Walker, J.C. (2001). The performance of the human nose in odour measurement. Water $\mathcal{E}$ Science Technology, Vol. 44, No. 9, pp. 1-7, ISSN 1606-9749

Wang, L.; Parker, D.B.; Parnell, C.B.; Lacey, R.E. \& Shaw, B.W. (2006). Comparison of CALPUFF and ISCST3 models for predicting downwind odor and source emission rates. Atmospheric Environment, Vol. 40, No. 25, (August 2006), pp 4663-4669, ISSN $1352-2310$

Wu, C.; Lin, M.; Feng , C.; Yang , K.; Lo , Y. \& Lo, J. (2003). M easurement of toxic volatile organic compounds in indoor air of semiconductor foundries using multisorbent adsorption/thermal desorption coupled with gas chromatography-mass spectrometry. Journal of Chromatography A, Vol. 996, No. 1-2, (May 2003), pp. 225231, ISSN 0021-9673

Young, P.J. \& Parker, A. (1983). The identification and possible environmental impact of trace gases and vapours in landfill gas. Waste Management $\mathcal{E}$ Research, Vol. 1, (January, 1983), pp. 213-226, ISSN 0734-242X

Yuwono, A.S. \& Lammers, P.S. (2004). Odor Pollution in the Environment and the Detection Instrumentation. Agricultural Engineering International: the CIGR Journal of Scientific Research and Development, Vol. VI, (July, 2004), pp. 1-33

Zou, S.C.; Lee, S.C.; Chan, C.Y.; Ho, K.F.; Wang, X.M.; Chan, L.Y. \& Zhang, Z.X. (2003). Characterization of ambient volatile organic compounds at a landfill site in Guangzhou, South China. Chemosphere, Vol. 51, No. 9, (June 2003), pp. 1015-1022, ISSN 0045-6535 


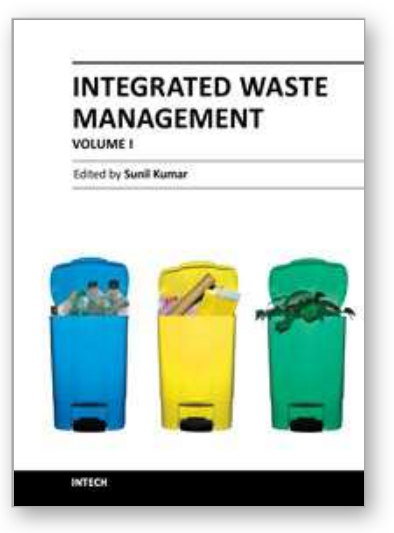

\author{
Integrated Waste Management - Volume I \\ Edited by Mr. Sunil Kumar
}

ISBN 978-953-307-469-6

Hard cover, 538 pages

Publisher InTech

Published online 23, August, 2011

Published in print edition August, 2011

This book reports research on policy and legal issues, anaerobic digestion of solid waste under processing aspects, industrial waste, application of GIS and LCA in waste management, and a couple of research papers relating to leachate and odour management.

\title{
How to reference
}

In order to correctly reference this scholarly work, feel free to copy and paste the following:

Magda Brattoli, Gianluigi de Gennaro and Valentina de Pinto (2011). Odour Impact Monitoring for Landfills, Integrated Waste Management - Volume I, Mr. Sunil Kumar (Ed.), ISBN: 978-953-307-469-6, InTech, Available from: http://www.intechopen.com/books/integrated-waste-management-volume-i/odour-impact-monitoring-forlandfills

\section{INTECH}

open science | open minds

\section{InTech Europe}

University Campus STeP Ri

Slavka Krautzeka 83/A

51000 Rijeka, Croatia

Phone: +385 (51) 770447

Fax: +385 (51) 686166

www.intechopen.com

\section{InTech China}

Unit 405, Office Block, Hotel Equatorial Shanghai

No.65, Yan An Road (West), Shanghai, 200040, China

中国上海市延安西路65号上海国际贵都大饭店办公楼405单元

Phone: +86-21-62489820

Fax: $+86-21-62489821$ 
(C) 2011 The Author(s). Licensee IntechOpen. This chapter is distributed under the terms of the Creative Commons Attribution-NonCommercialShareAlike-3.0 License, which permits use, distribution and reproduction for non-commercial purposes, provided the original is properly cited and derivative works building on this content are distributed under the same license. 